Article

\title{
Restoring the Feminine of Indigenous Environmental Thought
}

\author{
Margaret Forster \\ Te Pūtahi-a-Toi, School of Māori Knowledge, Massey University, Palmerston North 4442, New Zealand; \\ m.e.forster@massey.ac.nz
}

Received: 29 January 2019; Accepted: 12 March 2019; Published: 16 March 2019

\begin{abstract}
A feminist genealogy approach to governmentality is used to explore how indigenous knowledge and aspirations related to the environment become embedded into Aotearoa New Zealand environmental policy and practice. Particular consideration is given to the indigenous feminine as an impetus for change as expressed through atua wāhine/Māori female spiritual authority and powers. Political projects and activism by Māori, the indigenous people of Aotearoa New Zealand, provide the basis to explore contests between environmental truths that originate from Māori traditions and those that have come to dominate national environmental politics that originate from British "Western" traditions. It is argued that truth contests have been extremely effective at disrupting the power and authority of environmental policy and practice dominated by Western thought. Furthermore, efforts to maintain the momentum of these transformation and consolidate the authority and power of Māori communities is linked to rendering the indigenous feminine visible, retelling our herstories and developing new relationships and practices that give expression to atua.
\end{abstract}

Keywords: indigenous knowledge; resource management; feminine

Colonial gender rationalities actively oppressed the identity, authority and voice of women (Midgley 1998). This "logic" has been superimposed over the environment (Griffin 1978; Ruether 1975), which many cultures personify as a female, mother, nurturer and provider. As a consequence, the feminine in relation to environmental thought was either commodified, oppressed or deemed irrelevant to post-colonial resource management.

This paper uses a feminist genealogy methodology to trace the origins of this domination and oppression in Aotearoa New Zealand and in relation to the experiences of the local indigenous Māori people, and in particular Māori women. Of interest is the intersection of the indigenous political rights movement and dispersed approaches to governing, often referred to as government by distance, that enables Māori to contest dominant discourses associated with resource management. To this end, examples of the feminine in Māori environmental thought are used to demonstrate the power and prominent position of Māori women within the Māori world and to discern Māori environmental interests. The intent is to disrupt existing environmental truths, power and subjects, and to render visible the indigenous feminine in environmental thought as a means of imagining and enacting indigenous actions and behaviours that privilege sustainable development.

\section{Theoretical Perspectives}

As an indigenous scholar I am interested in privileging Māori knowledge and ways of knowing and advancing Māori political agendas—in this case exercising Māori authority over the tribal territory. Towards these ends I adapt three theoretical perspectives-a Māori approach to research, a genealogy approach to governmentality and feminist perspectives. This section makes explicit the contribution of each theoretical perspective to the feminist genealogies critique that is set out in the rest of the paper. 
A Māori approach to research encourages an inquiry that privileges Māori knowledge and ways of knowing, and advances Māori political projects (see for example Smith 1999). This approach places Māori culture at the centre of the research inquiry and sets the direction and intent of the study. In this paper I am interested in exploring a Māori cultural construction of the environment as a starting point for understanding why and how indigenous environmental sovereignty is assembled through policies and practices. Māori approaches to research are often preoccupied with resisting ongoing colonisation and the political project of decolonisation as a means of disrupting entrenched colonial and often patriarchal regimes of power.

A genealogy approach to governmentality promotes an unravelling of the historical processes that influence how we understand and make sense of the world and consequently the way we govern and are governed (Bevir 2010; Dean 1996; Rose and Miller 1992). In this context a genealogy approach is consistent with the Māori concept of whakapapa. Whakapapa as a noun can mean genealogy and lineage. As a verb it refers to the act of placing in layers or reciting in order. As a research approach it can involve understanding the way the world is ordered as a means of making sense of that world and mapping relationships, and consequently making explicit the in-built responsibilities and obligations of those relationships (Graham 2009; Te Rito 2007).

By situating this genealogy or whakapapa exploration within governmentality the critique becomes deliberately focused on political power, truths and governance, and, the possibility of thinking and acting in new ways. Such a critique as deployed in this paper focuses on the way we make sense of the world and how these understandings influence (or not) societal interactions with the environment. Reimagining the ways we govern and are governed is particularly attractive given that the dominant political system has struggled to recognise and create opportunities for Māori environmental interests.

When a feminist lens is introduced to this mix there is a deliberate focus on the feminine and responses to oppression and, in relation to the Aotearoa/New Zealand context, " $[\mathrm{t}]$ he need to write Māori women back into the records, to make ourselves visible" (Irwin 1992, p. 2). Such a critique is cognisant of the oppression of Māori as a consequence of colonisation. Furthermore, there is recognition that Māori women's experiences of oppression are different to those of non-Māori women. A feminist genealogy critique therefore is slightly at odds with a Māori research approach in that a focus on the feminine tells only part of the story. A focus on the feminine does not imply that the masculine is unimportant. The Māori worldview quite clearly promotes a complementary relationship between the genders; one cannot exist without the other.

To produce the critique outlined in this paper a Māori environmental worldview has been explored through a review of whakapapa, pūrākau/cultural narratives and literature. The analysis of kaitiakitanga and governance practices draws on research undertaken as part of a doctoral project that involved a review of Aotearoa New Zealand policy and practice, and interviews with kaitiaki/tribally appointed guardians of the environment.

As part of this feminist genealogy critique, a range of mātauranga Māori/Māori knowledge is shared. This information originates from publicly available sources as a deliberate strategy to respect the data sovereignty of tribes. The examples used here only scratch the surface. Māori are able to draw on a rich, varied and powerful archive to shape the way we understand and govern the environment.

\section{Rendering the Indigenous Feminine Visible}

When reviewing Aotearoa/New Zealand environmental policy it is possible to identify at least two enduring, and sometimes opposing, traditions (Brooking and Pawson 2011; Forster 2013, 2014; Young 2004). The oldest is associated with Māori communities, Māori being the indigenous peoples of Aotearoa New Zealand. This tradition is reflective of Māori worldviews, customary practices and political aspirations. The second tradition, which has come to dominate the contemporary environmental policy setting, was introduced as part of the British colonial project during the nineteenth century. This tradition privileges a man/Nature dichotomy where Nature is considered 
an object and products of "the 'labour' of nature such as soil, water, trees and minerals" (Dann 1992, p. 342) are attributed a lower value than the "labour" of man. Incidentally in this worldview the labour of women is accorded similar status as that of Nature. This way of perceiving the world has had a major influence on modern western politics (Dann 1992) including environmental management. It promotes an understanding of the environment (and women) as an object that can be dominated, subjugated and exploited. While there have always been challenges to this position (see for example Dann 1992; Royal 2007; Young 2004) a shift in environmental policy towards sustainable resource use is only a recent phenomenon. The critique that follows provides a genealogy of these traditions with the intent of making visible the contests between the two traditions. This critique provides the foundation for a commentary on efforts to transform governance of the Aotearoa/New Zealand environment.

\subsection{Truth-Telling}

I find it useful to think about a feminist genealogy approach to governmentality as a critique to trace the history of certain truths and the impact these truths have on the way we govern and are governed. The truths that are of interest to this paper are associated with the following questions: how and why has the concept of kaitiakitanga become expressed in Aotearoa/New Zealand environmental policy, and what difference would recognition of an indigenous feminine in the environment make to the way we govern and are governed?

This section of the paper begins with a brief definition of kaitiakitanga and a discussion of the ways it is expressed today. I then adopt a common Māori inquiry tradition of looking back to the past to make sense of the present and plan for the future. For instance, I consider why and how contemporary expressions of kaitiakitanga have been rendered visible and what truth contests have transpired for kaitiakitanga to be privileged in this way? To respond to this question an overview is provided of a Māori cultural construction of the environment. Part of this overview involves exploring the indigenous feminine and considering what implications it has for governance of the environment.

\subsection{Recognition of Māori Environmental thought in Policy}

Recognition and provisions for Māori environmental perspectives and interests have in recent times centred on the concept kaitiakitanga. The word kaitiakitanga is commonly translated as guardianship and has become closely associated with Māori environmental stewardship. Kaitiakitanga refers to the responsibility to "nurture and care" for the environment (Waitangi 2011, p. 5) and is exercised by tangata whenua/tribes that hold customary authority over an area, in accordance with tikanga/customary values and practices. A key imperative of kaitiakitanga is maintaining the mana/authority, and the mauri/spiritual essence, health and vitality of natural resources to protect their life-sustaining properties.

The use of the word kaitiakitanga (and its derivatives) began to emerge in the 1980s (Forster 2013) in relation to Waitangi Tribunal claims (political projects to reaffirm sovereignty over the tribal territory). The concept however originates from a set of values and practices that are much older (Roberts et al. 1995; Royal 2007). Consequently, to understand the contemporary practice of kaitiakitanga it is necessary to explore a Māori worldview. But first, what is kaitiakitanga and how does it manifest today?

Kaitiakitanga as an ethos provides the basis for Māori interactions, with the tribal territory determining appropriate relationships and practices (Kawharu 2000). Kaitiakitanga is political and concerned with indigenous rights. In a contemporary context it is a response to a colonial history that oppressed Māori understandings of the environment and ignored Māori environmental interests through imposing colonial frames over Māori bodies, communities and whenua/land. In this regard, assertions of kaitiakitanga demand recognition of mana whenua/local tribal authority in governance of the environment. Māori want increased control and authority over the ancestral landscape. This aspiration has been strongly articulated through Waitangi Tribunal claims, many of which were lodged by Māori women, environmental activists in their own right, such as Nganeko 
Minhinnick (Ngāti Te Ata Waiohua) and Dell Wihongi (Te Rarawa). These women have been instrumental in raising awareness of contemporary Māori environmental thought and interests, and contesting colonial frames of land ownership and environmental management (Forster et al. 2015). A critical outcome of these efforts has been the creation of opportunities to strengthen or resume customary environmental practices and working collaboratively with government agencies, other iwi/tribes, and others on shared environmental concerns. The recent Land and Water Forum ${ }^{1}$ is a good example of a national-level collaborative project. Also, kaitiakitanga has come to represent a Māori response to environmental degradation advocating for sustainable land use practices that protect the life-sustaining capability of the environment for present and future generations. For example, a number of hapu $/$ subtribes are actively engaged with local communities and government agencies in waterway and dune restoration projects and environmental monitoring (see for example Harmsworth et al. 2016; Selby et al. 2010; Tipa and Teirney 2003).

Kaitiakitanga was explicitly introduced into Aotearoa New Zealand environmental policy through the Resource Management Act 1991. This Act provides a political framework for the sustainable management of natural and physical resources in Aotearoa New Zealand. Contained within the Act are provisions for the relationship of Māori with ancestral lands, kaitiakitanga and rights as guaranteed under the Treaty of Waitangi ${ }^{2}$ (New Zealand Government 1991). Since 1991 Aotearoa/New Zealand policy has increasingly incorporated Māori political environmental aspirations and practices. For example, there is legislation, including the Fisheries Act 1996 and the Reserve Act 1977, and government agency policy, that provides for the practice of rāhui-the protection or setting aside of land or natural resources to protect spiritual and cultural values. This might mean restricting activities in a fishing reserve due to depleted resources or closing parts of a river for a short period of time due to a death (Maxwell and Penetito 2007).

Another example of the incorporation of Māori thought into environmental policy is the recent high-level recognition of the Wanganui River as a legal entity. Te Awa Tupua (Whanganui River Claims Settlement) Act 2017 declared the Whanganui River to be a legal person with "all the rights, powers, duties, and liabilities of a legal person" (section 14(1)). This is a significant shift in truth-telling. It directly challenges a conceptualisation of the environment as a mere commodity where economic concerns are the key consideration in decision-making. It emphasises instead a Māori worldview that values spiritual and cultural dimensions including ecological wellbeing. Decision-making around use of the Whanganui River and associated resources is collaborative and must take into account its legal status. While it is too early to determine the impact of this shift it does require a stronger focus on the health and wellbeing of the river.

Collaborations are becoming a key feature of Aotearoa New Zealand environmental governance that embody the political agenda of sustainability and indigenous rights and enact legislative intent. Collaborative management mechanisms are an example of government at a distance that provide for a range of activities by a multitude of actors, related to the management of natural resources. A variety of responses and relationships have emerged to address local needs and aspirations as Māori work with others to enhance the mauri/life force of the ancestral territory. Collaboration, usually with local government or government agencies, enables involvement at governance and operational levels, including creating opportunities for kaitiakitanga. Māori, as mana whenua/local tribal authority, are involved in the co-management of reserves, and the protection of the conservation estate and water bodies such as rivers, lakes, swamps and harbours. These relationships can be highly contentious as

1 The Land and Water Forum was established in 2009 and its most recent report was released in 2018. It brings together a range of stakeholders in freshwater and land management to help develop a shared vision and common direction for water management in New Zealand. A national programme has been developed to realise this vision.

2 The Treaty of Waitangi is often referred to as the founding document of Aotearoa New Zealand. It outlined a partnership between Māori and the British Crown providing details of the rights and responsibilities of each party (Orange 2012). 
competing traditions and agendas often permeate this space (Parliamentary Commissioner for the Environment 1998; Te Puni Kōkiri 2006).

Kaitiakitanga encapsulates Māori political aspirations towards the environment and loosely refers to those activities that provide for a customary relationship over the tribal territory. Kaitiakitanga as it is practiced today is quite diverse and its presence is increasingly linked to recognition of indigenous rights and acknowledged through legislative instruments. However, this does not tell us much about the values that underpin the practice. To understand what motivates the practice it is useful to explore a genealogy of kaitiakitanga that pays particular attention to the feminine.

\subsection{A genealogy of kaitiakitanga}

Ko Ranginui e tu iho nei

Ko Papatūānuku e takato ake nei

Ko Tāne Mahuta mā, ko te ira atua

Ka puta ko tātou, ko te ira tangata...

These words are part of a karakia or incantation written by licensed translator and Māori language resource developer Ian Christensen. The karakia draws on the power and authority of atua/Māori spiritual powers to guide those performing the karakia. The atua mentioned in this karakia are Ranginui/Sky Father, Papatūānuku/Earth Mother and Tāne Mahuta/"god" of the forest, representing the various "children" of Ranginui and Papatūānuku. The performance of karakia is a tangible reminder of the nature of the Māori world (known as Te Ao Māori) and the knowledge that is used to make sense of the world around us.

The Māori world has spiritual and physical dimensions. In this karakia, the spiritual is represented by Ranginui, Papatūānuku and Tāne Mahuta. The physical is represented by Tāne Mahuta and humanity (the words tātou, te ira tangata). Tāne Mahuta as a physical manifestation represents the various atua who reside over the natural realms. These atua are physically manifested in natural resources such as soil, flora and fauna, and forces such as wind, lightning and earthquakes. The various activities of humanity that occur in each domain and in relation to the natural resources and forces are negotiated with atua. According to this understanding of the world there is an interconnectedness between the spiritual and the physical and this association shapes the way we think and act.

Our contemporary understanding of this cultural construction of the environment has been heavily influenced by colonisation. The truths that have survived "discovery" by the "West" are fragmented and tainted by a foreign and often patriarchal lens. As a consequence, scholars argue that our truths have become simplified, "embellished" to appeal to European sensibilities, changed, or simply made-up to align with a male worldview and Christianity, thereby maintaining the power and authority of non-indigenous truths and practices (see for example Irwin 1992; Stewart-Harawira 2007; Mikaere 2003; Smith 1999). Below is a very short and generalised version of the Māori world. It does not convey the complexity or multiplicity of the full narrative but will suffice to provide readers with a basic understanding to engage with the critique that follows.

In the Māori story of creation, the earth and sky came together and gave birth to some 70 children, who eventually thrust apart their parents and populated the world. Each of the children became the god of a particular domain of the natural world. Their children and grandchildren then became ancestors in that domain. For example, Tangaroa, god of the sea, had a son called Punga. Punga then had two children: Ikatere, who became the ancestor of the fish of the sea, and Tùtewehiwehi, who became the ancestor of the fish and amphibious lizards of inland waterways. (Royal 2007)

Elsdon Best (1856-1931), an ethnographer whose work on Māori culture was particularly influential, provided "evidence" that the 70 children were "supernatural beings of the male sex" (Best 1976, p. 75). He described the atua as guardians or origins of natural resources or personifications of nature. He did identify atua who were female, although attributed these with lesser status than their 
male counterparts. His works provide some detailed knowledge associated with atua tāne/male spiritual authorities and powers, in particular: Tāne/origin of birds, Tūmatauenga/principal war-god, Rongo/god of peace and the art of agriculture, Tangaroa/ocean being, Tāwhirimātea/personified form of winds, Haumia/representing the aruhe or edible part of the fern, Whiro/representative of darkness and evil, Rūaumoko/representing earthquakes and all volcanic phenomena and Uru-te-ngangana/one of three guardians of the heavens and heavenly bodies. The English titles associated with these atua were provided by Best. The language does not do justice to the power and authority of the atua (i.e., use of the words "personified form" and "represents")and is heavily influenced by a Christian lens (i.e., use of the words "darkness and evil"). His work did identify atua wāhine/spiritual authorites and powers who were female. However the references and knowledge associated with atua wāhine were slight and tended to centre around sexual and reproductive function (Yates-Smith 2000, 2001, 2003). The implication was that atua wāhine authority and power was limited to a narrow range of domains and functions, and in general portrayed as unimportant and insignificant.

This construction of the feminine was consistent with representations of women of that time. This grand narrative and oppression of the feminine has been vehemently and convincingly challenged by Māori female scholars. There is a substantial body of work that makes explicit the ways that Māori women have been oppressed by colonization and demands a retelling of our herstories to empower not just women but also our communities (see for example Irwin 1992; Jenkins and Pihama 2001; Smith 1992). More recent works are challenging mainstream truths by providing Māori perspectives on issues such as birth and womanhood (Murphy 2014; Simmonds 2011) and parenting (Jenkins and Harte 2011). Pivotal critiques of atua wāhine include works by Māori scholars Aroha Yates-Smith (1998) and Mikaere (2003) and Māori artist Robyn Kahukiwa (Kahukiwa and Grace 1984).

Aroha Yates-Smith's (Tainui, Te Arawa) research on Māori goddesses (1998) reveals a detailed knowledge base that is predominantly oral rather than written. There is very little mention of goddesses in the pre-1880-1940 literature. The information that does exist:

Clearly indicate[s], the realm of the goddess is a rich and varied one, ranging from the celestial realm to the realms of sea and land, from seasons to the elements and atmospheric conditions. Indeed, specific reference is made to the diversity of functions performed by the various deities. (Yates-Smith 2001, p. 80)

Ani Mikaere's (Ngāti Raukawa, Ngāti Porou) work reveals how our truths, and specifically our narratives related to the feminine, have been distorted by colonisation. She critiques some of the grand narratives of our pūrākau/cultural narratives demonstrating how the status and roles of women have been reworked to privilege male actors and male actions. She retells our herstories stressing the centrality of female sexual and reproductive powers to the Māori world and the importance of enacting atua wāhine and wāhine knowledge to disrupt the impact of colonisation on whenua/land, Māori culture and Māori communities.

Robyn Kahukiwa (Ngāti Porou) is an artist who has created a number of pieces depicting atua wāhine and Māori women. Her work seeks to make visible the feminine within Māori culture. She has also collaborated with poet Roma Potiki to produce powerful works that foreground our knowledge around conception, gestation and birth.

Despite distortion of these truths, the importance of atua, both feminine and masculine, and interconnectedness in the Māori worldview persists. Interconnectedness is emphasised in a number of ways. For example, whakapapa/genealogy provides an insight into the way the world is ordered and outlines specific connections and relationships. The karakia, at the beginning of this section, names some key actors associated with the whakapapa sequence: Te Kore, Te Pō, Te Ao Mārama-the void, the darkness, the light. This whakapapa sequence provides an explanation of the evolution of the world from a place of darkness and potential to a world of light where humanity can flourish. The longer version of the sequence provides explanations for the nature and development of thought and the emergence of Ranginui and Papatūānuku (Royal 2007, p. 181). 
The sequence of Te Kore, Te Pō, Te Ao Mārama can be understood more deeply through kōrero tuku iho/ancient tribal narratives associated with the separation of Ranginui and Papatūānuku alluded to in Royal's (2007) generalised version of the Māori world (i.e., "70 children, who eventually thrust apart their parents and populated the world"). This narrative is enacted regularly today in customary practices such as pōwhiri/a Māori welcoming ceremony performed on marae/set of buildings and spaces that represent the political and cultural power of the tribe or local Māori community. When guests are formally welcomed onto a marae, they move through the stages of Te Kore and Te Pō to Te Ao Mārama. For example, at the gateway to the marae guests are deemed to be in a state of Te Kore; who they are, and their intent are unknown. As they progress through the pōwhiri ceremony and physical spaces on the marae they introduce themselves to the host and begin the process of relationship building. This is the state of Te Pō. Once the ceremony is complete, they are known and have reached the state of Te Ao Mārama.

Perhaps the most direct expression of interconnectedness is whakapapa that outlines specific genealogical connections. Some tribes are direct descendants of atua. For example, the Ngāti Porou tribe trace their whakapapa back to Papatūānuku and Tūhoe people whakapapa to Hinepūkohurangi/atua wahine of mist that surrounds the mountain. Whakapapa identifies a number of atua wāhine.

Papatūānuku is probably the most well-known. She is portrayed as the first mother.

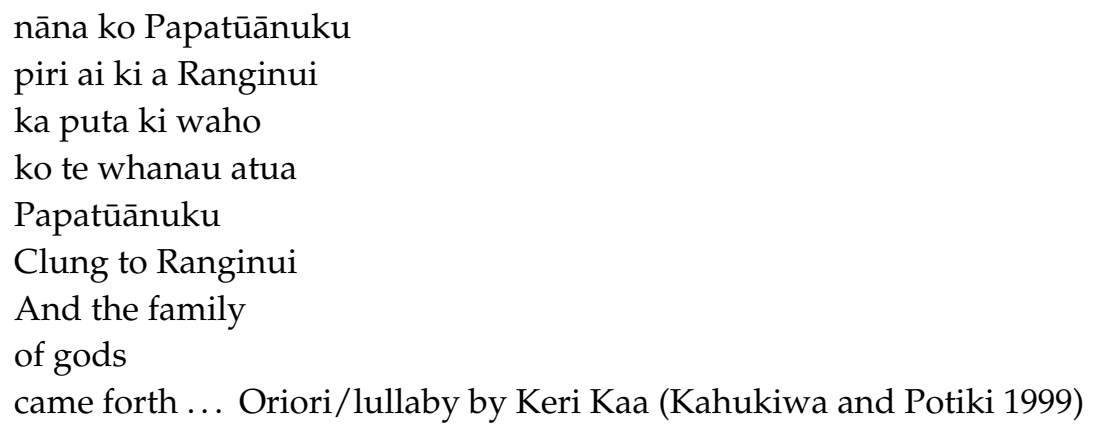

She is also a personification of the Earth and sustains all life.

My flesh, muscle, sinew, and cartilage are composed of rock, granite, dirt, mud, stone, sand, and all that is dense and solid.

My bones are fossilised trees, veins of granite, gold, silver, copper, and all precious metals, branching from my core, from the centre of my being.

My blood is molten lava, liquid rock, water, boiling mud, nourishing bone and flesh through a labyrinth of rigid veins.

My breath is sulphur, gas, air, and mist, seeping through countless layers of hardened skin, a skin of regenerating life. Life for my children, my grandchildren, and the countless offspring which derive from them. They are the forests, plants, seas, rivers and creatures which clothe me. They are my wondrous korowai [cloak] which sustains us all. (Grace n.d.)

Cultural narratives associated with Papatūānuku remind us of the importance of whānau/family and the nature of our relationship with the environment. While her reproductive and life-sustaining powers are emphasised, her role as knowledge-holder is also acknowledged (Mikaere 2003).

Some of the offspring of Papatūānuku are atua wāhine, or produced atua wāhine or natural resources or natural phenomena, with a distinct female identity. The table that follows (Table 1) provides some examples of atua wāhine: 
Table 1. Examples of atua wāhine.

ATUA WĀHINE ASSOCIATED WITH THE STARS: Moeāhuru/mother of heavenly bodies; Matariki, Tupu-ā-nuku, Tupu-ā-rangi, Waipunarangi, Waitī, Waitā and Ururangi/the Pleiades star cluster; Hinenuitepoteao/sunlight and stardust; Hineteiwaiwa/goddess of the moon and reproductive cycle of women, she who resides over women's esoteric knowledge and ceremonial arts

ATUA WĀHINE ASSOCIATED WITH THE SKY: Hinekōrako/lunar halo or bow; Hinewai/fine mist-like rain; Hinekohu/mist; Whaitiri/thunder; Pārāweranui/mother of wind children

ATUA WĀHINE ASSOCIATED WITH MOUNTAINS: Hine Tupai Maunga/mountains and cliffs; Tapeka representing subterranean fire

ATUA WĀHINE ASSOCIATED WITH THE WATER AND ROCK: Parawhenuamea/Water that springs forth from the earth; Hine māheri/fine-grained sandstone

ATUA WAHINE ASSOCIATED WITH THE SEA: Hinemoana/goddess of the sea

ATUA WĀHINE ASSOCIATED WITH PLANTS AND BIRDS: Hinekotauariki/origin of aruhe or fern root; Hinepūtehue/origin of gourd; Punaweko origin of land birds; Hurumanu origin of sea birds.

ATUA WĀHINE ASSOCIATED WITH SEASONS AND TIME: Hineraumati/summer; Hinetakurua/winter; Hineata/morning; hineahiahi, evening

Source: (Best 1976, 1982). Note: This is not a definitive list and names may differ between tribes.

This information is much more than a list of names. Each name represents a body of knowledge and practices associated with a particular environmental domain. For example, Parawhenuamea is referred to as water that springs forth from the land. Her name alludes to an understanding of the water cycle and the relationship between the sky, land, rivers and sea. Whakapapa associated with Parawhenuamea (See Figure 1) links her to natural features associated with river systems—cliffs and different types of rocks and stones.

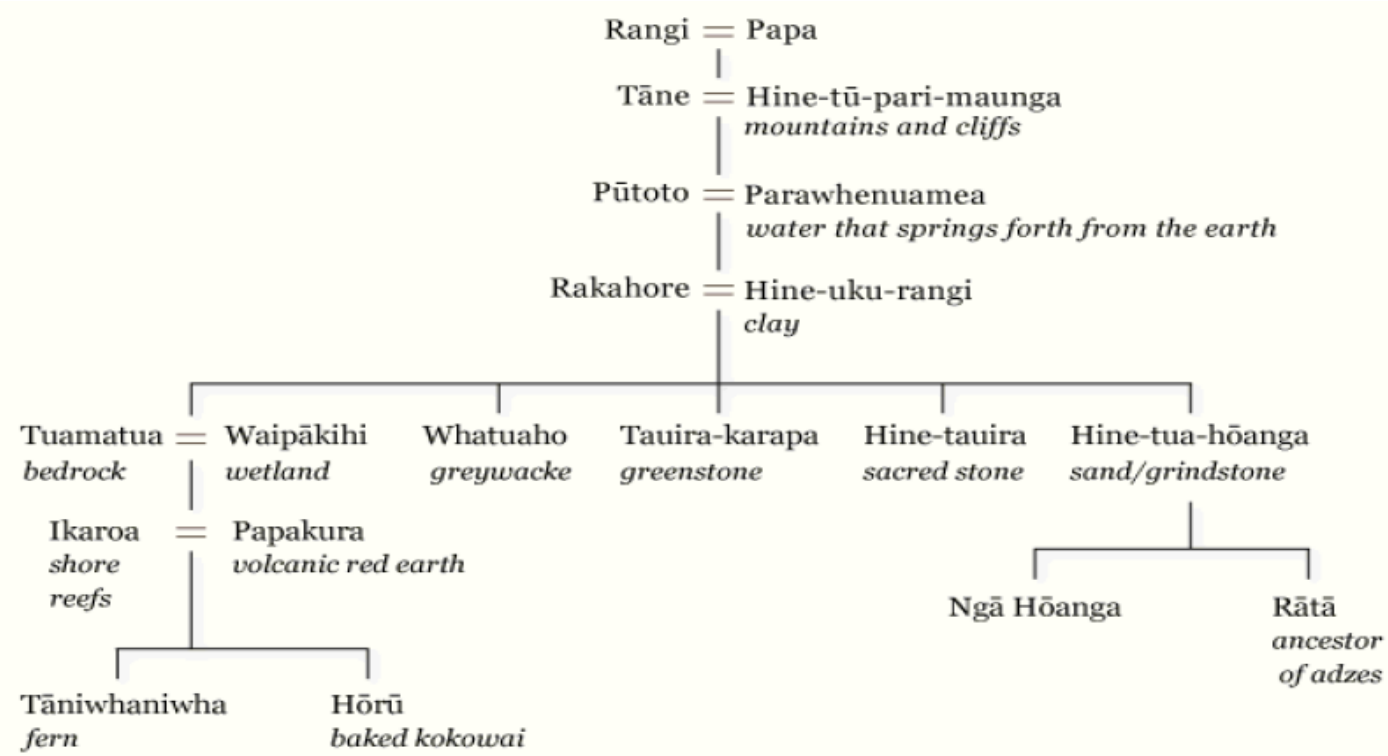

Figure 1. Whakapapa for Parawhenuamea. Source: (Moore and McFadgen 2006).

Ihirangi Heke, Tainui Waikato physical activity consultant, has adapted the power and authority of Parawhenuamea and knowledge associated with her domain to motivate Māori to be active in water (Heke n.d.). He advocates connecting with Parawhenuamea through learning of whakapapa, narratives and the personality traits of the various forms of water. Understanding that the movement of water is dependent on the land and stones around it provides a basis for thinking about exercise and resistance training. He calls this way of thinking Atua Matua Māori Health Framework (Heke 2017). This is an example of the application of atua wāhine to address a pressing contemporary health and wellbeing issue of inactivity. 
Within a Māori worldview, specific natural resources can also possess a gendered identity. For example, Taranaki mountain is considered to be a male and he resides next to Pouākai a female mountain range (Taranaki Iwi n.d.). Another mountain example is Tongoriro (male) and Pihanga (female) (Taranaki Iwi n.d.) in the central plateau region of the North Island. The Ngāti Kōhatu people have a pūrākau/tribal narrative that identifies the Ruakituri River as male and the Hangaroa River as female (Iwi and Hapū of Te Rohe o Te Wairoa and the Crown 2016). Incidentally, this pūrākau is about two taniwha/water spirits and guardians who race to the sea. Ruamano, a male taniwha created the Ruakituri River and Hinekōrako created the Hanagroa River. These rivers converge at Te Reinga Falls to produce the Wairoa River which is a significant cultural resource for the tribes in the Wairoa region. What is interesting about this example is the emphasis on the presence of a feminine and masculine principle for producing a new entity-the Wairoa river. This example is a reminder of the complementary relationship of gender in Māori environmental thought.

Other well-known atua wāhine are linked to human activity or associated with specific natural resources. For example, Mahuika is known as the guardian of fire that resides in certain trees (Best 1976, 1982) and the power of Hineteiwaiwa is evoked in relation to womanhood, childbirth, parenting, the performing arts and weaving (see for example Yates-Smith 1998; Simmonds 2011; Murphy 2014).

This critique does not claim to be definitive. The intent is to demonstrate the richness of the feminine in Māori environmental thought. Atua wāhine were a common and important feature of the Māori worldview. Their presence shapes a cultural environmental perspective and codifies a set of environmental responsibilities, known today as kaitiakitanga, to guide human interactions with the environment. A Māori world premised on atua and interconnectedness through kinship advocates for relationships that are enduring, reciprocal and life-sustaining.

\section{Atua and Environmental Governance}

Atua have always been central to a Māori worldview. Their presence in the Māori consciousness, the tribal territory and our daily indigenous lives provides a basis for making sense of the world-in the past, the present and in the future. The atua presence emphasises the importance of the spiritual and interconnectedness. Some atua embody the feminine or the masculine and are involved in mutual interactions that strive to achieve complementarity, balance and harmony. The world therefore is dynamic, continuously responding to the interaction of these forces, transforming the world, thoughts and actions. When this knowledge and way of thinking is related to the environment, the natural world is embodied, knowing and powerful. In this context, the word embodied is used to refer to a holism dependent on interconnectedness. For example, a river has spiritual elements in the form of atua such as Parawhenuamea. Some rivers have spiritual guardians or kaitiaki known as taniwha. Both the atua and kaitiaki perform protective functions in relation to natural resources and human activities. The spiritual elements therefore shape appropriate actions and resource use. Rivers have economic and social elements and provide the physical sustenance for communities to thrive and, precontact, were important transport hubs. Finally, Māori have always possessed a deep ecological understanding of the environment. A river is part of a "system" that is connected to a water cycle that involves elements and forces present in the atmosphere. Water sources can originate from mountains or underground. Rivers connect mountains to the sea. Rivers engage with a wide range of natural resources-wind, soil, rocks, flora and fauna. These aspects of the environment are acknowledged in whakapapa and through the presence of atua responsible for specific domains, cycles and natural resources, in this way preserving the integrity of the system as a whole and also the integrity of its parts. The atua presence obligates Māori communities to act in a manner that enhances the mana/power and authority of the "system" thereby promoting health and well-being and sustainable resource use. These obligations find expression today in the exercise of mana whenua/local tribal authority and kaitiakitanga local customary environmental practices. However, the influence of a Māori understanding of the world today and the prevalence of customary practices have been disrupted by colonisation. 
The British colonial project introduced new environmental truths into the Aotearoa New Zealand political landscape. British understandings of appropriate land use and land tenure displaced Māori understandings. The presence of atua was relegated to the periphery, excluded from the land ownership and resource use discourse and confined instead to discussions of religion. As part of this shift in thought and power atua wāhine were rendered invisible in the written archives. Atua wāhine were mentioned sporadically and very few details recorded (Yates-Smith 2000, 2001). Today, much of the knowledge associated with atua wāhine resides within Māori oral traditions and customary practices.

The absence of the feminine is not limited to the environmental sphere. The identity and authority of Māori women was also systematically undermined by colonisation (see for example Irwin 1992) further compromising recognition, knowledge and practices associated with the atua wāhine-women-whenua relationship.

Efforts to respond to the British colonial project and restore the mana/power and authority of atua wāhine, Māori women and whenua centre around making explicit the value of the feminine as encapsulated in a Māori worldview. Māori women are engaged in reclaiming knowledge of atua wāhine to shape the way we respond to contemporary situations and issues. Reconnecting with feminine authority and power is a strategy for building secure indigenous feminine identities and self-esteem, thereby contesting the oppression of Māori women. Also, a greater acknowledgement of atua, both feminine and masculine, can contest dominant environmental thought, institutions and practices. The presence of atua as natural forces and natural resources is a reminder of the spiritual dimensions of the environment and invites a reimagining of the way the environment is understood and what counts as appropriate relationships and actions. Legislative provisions that acknowledge mana whenua and provide opportunities for kaitiakitanga create spaces for Māori knowledge and ways of knowing to be normalised into local government policy and practices. This is reflected by the inclusion of Māori perspectives of the environment and Māori interests in regional planning documents and the development of Māori environmental tools for assessing the cultural health of the environment, such as the cultural health index (Tipa and Teirney 2003) and various mauri evaluation models (Harmsworth et al. 2016). These strategies promote environmental practices that endorse interconnectedness, health and wellbeing and sustainable development.

The extent to which Māori understandings influence environmental decision-making and practice is difficult to determine. The dispersed nature of local government promotes local responses, so incorporation of Māori understandings and agendas are dependent on how well local actors can disrupt the status quo. Consequently, there is considerable variation across the country in the ways that Māori thought is incorporated into environmental policy and practice. Māori activism and knowledge contests therefore are critical strategies for ensuring that Māori interests continue to influence the way we govern and are governed. The dispersed and dynamic nature of this space is a key for responding to new situations and new challenges at the local level. For example, new technologies such as fracking ${ }^{3}$ can be conceptualised through a Māori analytic view to aid decision-making. Also, climate change affects areas differently, so for some the focus might mean access to water or responding to increasing sea levels. Kaitiakitanga as a form of governance is therefore highly adaptable and relevant over a range of domains and in relation to a variety of environmental issues.

\section{Conclusions}

This paper has deployed a feminist genealogy critique of environmental governance in Aotearoa New Zealand by tracing the influence of atua wāhine and the practice of kaitiakitanga on the way the environment is conceptualised and governed. It is argued that atua wāhine have always been a central part of the Māori worldview, but their significance has been disrupted and downplayed by colonisation.

3 Fracking involves drilling down into the earth and injecting a high-pressure water mixture to extract gas and oil. It is a relatively new process that has attracted considerable criticism from indigenous peoples and environmentalists. 
Political projects that challenge and resist this subordinate positionality have enabled a Māori worldview to be incorporated into policy that finds expression through the practice of kaitiakitanga. The presence of kaitiakitanga continually contests other environmental truths. Furthermore, reclaiming the power and authority of atua, the feminine and masculine forms, is an effective way to rethink contemporary interactions with the environment to promote interactions that are enduring, reciprocal and life-sustaining.

Acknowledgments: Tēnei te mihi kau ana ki ngā kaitiaki i te motu. Nā koutou mahi, ka ora ai te whenua, ka ora ai te iwi. This paper was developed as part of He Tātai Whenua, a Ministry of Business Innovation and Enterprise funded project developing a Māori landscape classification system.

Conflicts of Interest: The funders had no role in the design of the study; in the collection, analyses, or interpretation of data; in the writing of the manuscript, or in the decision to publish the results.

\section{Glossary}

$\begin{array}{ll}\text { Aotearoa } & \text { Māori name for New Zealand } \\ \text { Atua } & \text { Māori spiritual power and authority. Atua wāhine refer to atua that are } \\ & \text { intrinsically feminine and atua tāne can be used to refer to atua that are masculine } \\ \text { Hapu } & \text { Subtribes } \\ \text { Iwi } & \text { Tribes } \\ \text { Kaitiaki } & \text { Guardian } \\ \text { Kaitiakitanga } & \text { Māori environmental ethos and practices } \\ \text { Karakia } & \text { Incantation, ritual chant } \\ \text { Mana } & \text { Power and authority } \\ \text { Mana whenua } & \text { Local tribal authority } \\ \text { Māori } & \text { Indigenous people of Aotearoa } \\ \text { Marae } & \text { A communal area and meeting grounds of mana whenua } \\ \text { Mauri } & \text { Life force } \\ \text { Pōwhiri } & \text { Customary welcoming ceremony } \\ \text { Pūrākau } & \text { Cultural narrative } \\ \text { Rāhui } & \text { Temporary restriction over an area or a natural resource } \\ \text { Tangata Whenua } & \text { Tribe with customary authority over a specific area } \\ \text { Taniwha } & \text { Water spirit and guardian } \\ \text { Te Ao Māori } & \text { The Māori world } \\ \text { Whakapapa } & \text { Genealogy } \\ \text { Whenua } & \text { Land, tribal territory }\end{array}$

\section{References}

Best, Elsdon. 1976. Māori Religion and Mythology Part 1; Wellington: Government Printer. Available online: http:/ / nzetc.victoria.ac.nz/tm/scholarly/tei-Bes01Reli.html (accessed on 15 January 2019).

Best, Elsdon. 1982. Māori Religion and Mythology Part 2; Wellington: Government Printer. Available online: http:/ / nzetc.victoria.ac.nz/tm/scholarly/tei-Bes02Reli.html (accessed on 15 January 2019).

Bevir, Mark. 2010. Rethinking governmentality: Towards genealogies of governance. European Journal of Social Theory 13: 423-11. [CrossRef]

Brooking, Tom, and Eric Pawson. 2011. Seeds of Empire: The Environmental Transformation of New Zealand. London: I. B. Tauris.

Dann, Christine. 1992. Ecofeminism, women and nature. In Feminist Voices. Women's Studies Texts for Aotearoa/New Zealand. Edited by Rosemary Du Plessis, Phillida Bunkle, Kathie Irwin, Alison Laurie and Sue Middleton. Auckland: Oxford University Press, pp. 338-53.

Dean, Mitchell. 1996. Foucault, government and the enfolding of authority. In Foucault and Political Reason: Liberalism, Neo-Liberalism and Rationalities of Government. Edited by Andrew Barry, Thomas Osborne and Nickolas Rose. London; New York: Routledge, pp. 209-29.

Forster, Margaret Edith. 2013. Imagining new futures: Kaitiakitanga and Agri-Foods. New Zealand Sociology 28: 9-32. 
Forster, Margaret Edith. 2014. Indigeneity and trends in recognizing Māori environmental interests in Aotearoa New Zealand. Nationalism and Ethnic Politics 20: 63-78. [CrossRef]

Forster, Margaret Edith, Farah Palmer, and Shirley Barnett. 2015. Karanga mai rā: Stories of Māori women as leaders. Leadership 12: 324-45. [CrossRef]

Grace, Wiremu. n.d. A Trilogy of Wahine Toa. Available online: http:/ / eng.mataurangamaori.tki.org.nz/Rauemitautoko/Te-Reo-Maori/Nga-Pakiwaitara-Maori-me-nga-Purakau-Onaianei/He-raupapa-toru-o-ngawahine-toa (accessed on 15 January 2019).

Graham, James. 2009. Nā Rangi tāua, nā Tūānuku e takoto nei: Research methodology framed by whakapapa. MAI Review 1: 3.

Griffin, Susan. 1978. Women and Nature: The roaring Inside Her. San Francisco: Harper and Row.

Harmsworth, Garth, Shaun Awatere, and Robb Mahuru. 2016. Indigenous Māori values and perspectives to inform freshwater management in Aotearoa-New Zealand. Ecology and Society 21: 9-23. [CrossRef]

Heke, Ihirangi. 2017. Introducing the Atua Matua Māori Health Framework. Available online: https://toitangata. co.nz/our-mahi/atua-matua/ (accessed on 15 January 2019).

Heke, Ihirangi. (n.d.) A Video on Parawhenuamea and physical activity. Available online: https://www.youtube. com/watch?v=Gsw-33jf_JQ (accessed on 15 January 2019).

Irwin, Kathie. 1992. Towards Theorises of Māori Feminism. In Feminist voices. Women's Studies Texts for Aotearoa/New Zealand. Edited by Rosemary Du Plessis, Phillida Bunkle, Kathie Irwin, Alison Laurie and Sue Middleton. Auckland: Oxford University Press, pp. 1-21.

Iwi and Hapū of Te Rohe o Te Wairoa and the Crown. 2016. Deed of Settlements Schedule: Documents; Wellington: Office of Treaty Settlement. Available online: https:/ / www.govt.nz/dmsdocument/6703-te-wairoa-iwiand-hapu-deed-of-settlement-schedule-documents (accessed on 15 January 2019).

Jenkins, Kuni, and Helen Mountain Harte. 2011. Traditional Māori parenting. An Historical Review of Literature of Traditional Māori Child Rearing Practices in Pre-European Times. Auckland: Te Kāhui Mana Ririki, Available online: http:/ / www.ririki.org.nz/wp-content/uploads/2015/04/TradMaoriParenting.pdf (accessed on 15 January 2019).

Jenkins, Kuni, and Leonie Pihama. 2001. Mātauranga wahine: Teaching Māori women's knowledge alongside feminism. Feminism and Psychology 11: 293-303. [CrossRef]

Kahukiwa, Robyn, and Patricia Grace. 1984. Wāhine Toa: Women of Māori Myth. Auckland: Collins.

Kahukiwa, Robyn, and Roma Potiki. 1999. Oriori. A Māori Child is Born-From Conception to Birth. Auckland: Tandem Press.

Kawharu, Merata. 2000. Kaitiakitanga: A Māori anthropological perspective of the Māori socio-environmental ethic of resource management. Journal of the Polynesian Society 109: 349-70.

Maxwell, Kimberley H., and Wally Penetito. 2007. How the use of rāhui for protecting taonga has eveoled over time. MAI Review 2. Available online: http:/ / review.mai.ac.nz/MR/article/download/58/58-69-1-PB.pdf (accessed on 15 January 2019).

Midgley, Clare. 1998. Gender and Imperialism. Manchester: Manchester University Press.

Mikaere, Ani. 2003. The Balance Destroyed. Consequences for Māori women of the Colonisation of Tikanga Māori. Auckland: The International Research Institute for Māori and Indigenous Education.

Moore, Phil, and Bruce McFadgen. 2006. Kōhatu-Māori Use of Stone. Te Ara-The encyclopedia of New Zealand. Available online: https://teara.govt.nz/en/whakapapa/9372/whakapapa-of-putoto (accessed on 15 January 2019).

Murphy, Ngahuia. 2014. Waiwhero. The Red Waters. A Celebration of Womenhood. He Whakahirahiratanga o te Ira Wahine. Ngaruawahia: He Puna Manawa.

New Zealand Government. 1991. Resource Management Act 1991. Available online: http:/ /www.legislation.govt. nz/act/public/1991/0069/latest/DLM230265.html?src=qs (accessed on 11 January 2019).

Orange, Claudia. 2012. Treaty of Waitangi. Te Ara-the encyclopedia of New Zealand. Available online: http:/ / www.TeAra.govt.nz/en/treaty-of-waitangi (accessed on 11 January 2019).

Parliamentary Commissioner for the Environment. 1998. Kaitiakitanga and Local Government: Tangata Whenua Participation in Environmental Management. Wellington: Author.

Roberts, Mere, Waerete Norman, Nganeko Minhinnick, Dell Wihongi, and Carmen Kirkwood. 1995. Kaitiakitanga: Māori perspectives on conservation. Pacific Conservation Biology 2: 7-20. [CrossRef] 
Rose, Nikolas, and Peter Miller. 1992. Political power beyond the state: Problematics of government. The British Journal of Sociology 34: 173-205. [CrossRef]

Royal, Charles. 2007. Te Ao Mārama-The Natural World-An Interconnected World. Te Ara-The Encyclopedia of New Zealand. Available online: http:/ / www.TeAra.govt.nz/en/te-ao-marama-the-natural-world/page2 (accessed on 11 January 2019).

Ruether, Radford. 1975. New Women New Earth. New York: Seabury Press.

Selby, Rachel, Malcolm Mulholland, and Pataka Moore. 2010. Māori and the Environment: Kaitiaki. Wellington: Huia Publishers and Te Wānanga-o-Raukawa.

Simmonds, Naomi. 2011. Mana wahine: Decolonising politics. Women's Studies Journal 25: 11-25.

Smith, Linda Tuhiwai. 1992. Māori women: Discourses, projects and mana wahine. In Women in Education in Aotearoa 2. Edited by Sue Middleton and Alison Jones. Wellington: Bridget Williams Books, pp. 33-51.

Smith, Linda Tuhiwai. 1999. Decolonizing Methodologies: Research and Indigenous Peoples. London: Zed Books.

Stewart-Harawira, Makere. 2007. Practising indigenous feminism: Resistance to imperialism. In Making Space for Indigenous Feminism. Edited by Joyce Green. Winnipeg: Fernwood Publishing, London: Zed Books, pp. 124-39.

Taranaki Iwi. n.d. Our History. Available online: https://taranaki.iwi.nz/our-history/ (accessed on 16 January 2019).

Te Puni Kōkiri. 2006. Te Kotahitanga o te Whakahaere Rawa: Māori and Council Engagement under the Resource Management Act 1991. Wellington: Author.

Te Rito, Joseph Selwyn. 2007. Whakapapa: A framework for understanding identity. MAI Review 1: 10.

Tipa, Gail, and Laurel D. Teirney. 2003. A Cultural Health Index for Streams and Waterways: Indicators for Recognising and Expressing Māori Values; Wellington: Ministry for the Environment.

Waitangi, Tribunal. 2011. Ko Aotearoa Tēnei. A Report into Claims Concerning New Zealand Law and Policy Affecting Māori Culture and Identity. Te Taumata Tuatahi. Wellington: Waitangi Tribunal.

Yates-Smith, Aroha. 1998. Hine! E Hine! Rediscovering the Feminine in Māori Spirituality. Ph.D. thesis, University of Waikato, Hamilton.

Yates-Smith, Aroha. 2000. Māori goddesses in literature Part 1: Pre-1880-1900. Journal of Māori and Pacific Development 1: 73-96.

Yates-Smith, Aroha. 2001. Māori goddesses in literature Part 2: 1900-1940. Journal of Māori and Pacific Development 2: 67-96.

Yates-Smith, Aroha. 2003. Reclaiming the ancient feminine in Māori society. 'Kei wareware i a tātou te ūkaipō'. Journal of Māori and Pacific Development 4: 10-19.

Young, David. 2004. Our Islands, Our Selves. A History of Conservation in New Zealand. Dunedin: Otago University Press.

(C) 2019 by the author. Licensee MDPI, Basel, Switzerland. This article is an open access article distributed under the terms and conditions of the Creative Commons Attribution (CC BY) license (http:/ / creativecommons.org/licenses/by/4.0/). 